\title{
PENGEMBANGAN ALAT ROTARY TABLE PADA KOMPETENSI CETAK SARING PROGRAM KEAHLIAN DESAIN DAN PRODUKSI KRIYA TEKSTIL SMK NEGERI 1 SUKASADA
}

\author{
Andi Wadi \\ Guru SMKN 1 Sukasada, Buleleng, Bali \\ Email: wadiandi46@gmail.com
}

\begin{abstract}
Abstrak
Penelitian ini bertujuan untuk mengembangkan alat bantu pada kompetensi cetak saring, dengan menggunakan metode Research and Development $(R \& D)$. Analisis data dan uji coba produk melalui eksperimen model before-after. Uji signifikansi dengan statistik komparasi paired sampel t-test dilakukan untuk mengetahui keefektifan penggunaan alat lama dan alat hasil pengembangan. Hasil uji keefektifan menunjukkan perbandingan alat lama dengan alat rotary table pada aspek kecepatan 90\%: 79\%, aspek ketepatan 91\%:84\% dan aspek kerapian 90\%: 83\%, rata-rata 91\%:82\% dengan nilai korelasi sebesar -0,40. Hasil uji signifikansi uji satu pihak dengan taraf kesalahan 5\%, diperoleh harga t-tabel sebesar 1,77 sedangkan t-hitung sebesar-12,6. Berdasarkan hasil uji keefektifan menunjukkan bahwa penggunaan alat Rotary Table hasil pengembangan lebih efektif dari penggunaan alat yang lama. Dengan demikian disimpulkan bahwa terdapat perbedaan yang signifikan keefektifan penggunaan alat Rotary Table yang baru dan lama.
\end{abstract}

Kata kunci: Pengembangan, Rotary Table, Cetak Saring, Desain dan Produksi Kriya.

\begin{abstract}
This study aims to develop tools for filter print competence, using the Research and Development $(R \& D)$ method. Data analysis and product trials through before-after model experiments. Significance test with comparative statistics paired sample t-test was conducted to determine the effectiveness of the use of old tools and tools developed. The results of the effectiveness test showed a comparison of old tools with rotary table at 90\%: 79\% speed aspect, 91\%: $84 \%$ accuracy aspect and 90\%: 83\% neatness aspect, on average 91\%: 82\% with a correlation value of -0, 40. Test results of the significance of one-party test with an error level of 5\%, obtained t-table prices of 1.77 while the t-test of -12.6. Based on the results of the effectiveness test shows that the use of the Rotary Table results of the development is more effective than the use of the old tool. This paper concluded that there were significant differences in the effectiveness of the use of new and old Rotary Table tools.
\end{abstract}

Keywords: Development, Rotary Table, Screen Printing, Craft Design and Production.

\section{LATAR BELAKANG}

Kompetensi cetak saring merupakan salah satu kompetensi utama pada program keahlian Desain dan Produksi Kriya (DPK) Tekstil yang mengedepankan ketelitian, ketepatan dan kerapian hasil cetak. 
Salah satu kesulitan pelaksanaan pemelajaran praktek bagi siswa dirasakan terutama saat melakukan presisi gambar pada desain cetak saring yang multi colour.

Ketidaktersediaan alat bantu yang memadai berdampak pada kurang efisien dan efektifnya proses dan hasil cetak yang dilakukan oleh siswa. Di samping membutuhkan waktu yang lama juga kualitas produk yang dihasilkan kurang rapi karena tidak presisinya dalam penempatan warna sesuai dengan desain.

Hal ini dapat dipahami mengingat bahwa untuk memperoleh gambar yang utuh dengan jumlah warna sesuai desain, harus menggunakan klise/film sejumlah warna yang ada pada desain, dan dilakukan proses cetak sebanyak jumlah warna yang diinginkan. Artinya satu warna, satu klise, satu kali cetak, dua warna berarti dua klise, dua kali mencetak, tiga warna berarti tiga klise, tiga kali proses percetakan, dan demikian seterusnya.

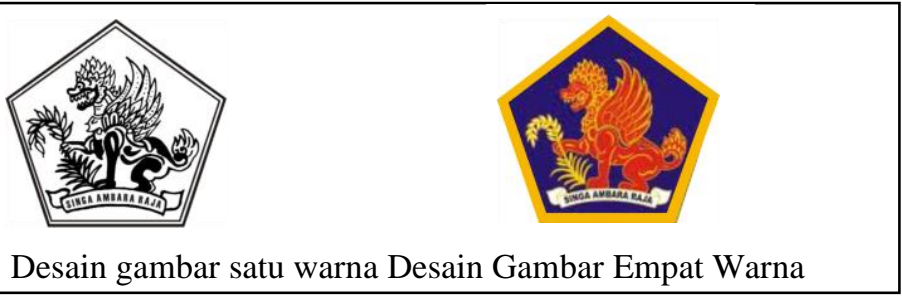

Gambar 1. Contoh Gambar Satu Warna dan Empat Warna Untuk Cetak Saring

Dari kedua desain gambar pada gambar 1, terlihat pada gambar sebelah kiri hanya terdiri dari warna hitam, sehingga jika akan dicetak cukup menggunakan satu alat cetak/screen dan mencetaknya hanya satu kali saja. Sedangkan gambar sebelah kanan terdiri dari empat warna yaitu warna biru sebagai warna latar, warna oranye kekuningan sebagai warna kontur, warna merah adalah warna objek berbentuk gambar Singa, dan warna hitam pada tulisan yang sekaligus biasanya sebagai pengikat dari warna lainnya. Jika akan dicetak maka diperlukan empat cetak/screen sesuai dengan jenis warnanya yaitu sebanyak empat buah screen.

Proses pencetakan dilakukan satu demi satu warna dan hasilnya harus presisi, dalam proses cetak saring disebut dengan istilah centering yang dapat diartikan bahwa masing-masing warna harus tepat pada posisi sambung dengan warna lainnya, sehingga membentuk satu kesatuan gambar yang utuh dan tidak terlihat adanya penumpukan atau pemisahan warna yang terlalu jauh dari warna lainnya. Tolok ukur keberhasilan hasil cetakan yang baik antara lain memiliki warna yang rata, penempatan warna presisi tepat dalam satu kesatuan dan beberapa indikator lainnya.

Berdasarkan observasi dokumentasi hasil pemelajaran kompetensi cetak saring pada kelas XI program keahlian desain dan Produksi Kriya Tekstil pada tiga tahun terakhir diperoleh data sebagai berikut: 
Tabel 1. Hasil Belajar Siswa Kelas XI Tekstil Kompetensi Cetak Saring

Aspek Penilaian : Printing (cetak)

\begin{tabular}{ccccccc}
\hline No & $\begin{array}{c}\text { Tahun } \\
\text { Pelajaran }\end{array}$ & $\begin{array}{c}\text { Kecepatan } \\
\text { (waktu) }\end{array}$ & $\begin{array}{c}\text { Ketepatan } \\
\text { (presisi) }\end{array}$ & $\begin{array}{c}\text { Ketajaman } \\
\text { (warna) }\end{array}$ & $\begin{array}{c}\text { Ketelitian } \\
\text { (bersih) }\end{array}$ & NA \\
\hline 1 & $2014-2015$ & 6.8 & 7.0 & 7.5 & 7.5 & 7.2 \\
2 & $2015-2016$ & 7.2 & 7.5 & 8.0 & 7.5 & 7.6 \\
3 & $2016-2017$ & 7.0 & 7.0 & 8.0 & 7.5 & 7.4 \\
\hline \multicolumn{2}{c}{ Rata- Rata } & 7.0 & 7.2 & 7.8 & 7.5 & 7.4 \\
\hline
\end{tabular}

Sumber: Dokumen guru mata diklat cetak saring

Salah satu penyebab rendahnya hasil belajar siswa tersebut diperkirakan adalah penggunaan alat cetak di sekolah yang masih manual, sederhana sebagai akibat kurangnya sarana pendukung dalam kegiatan praktik yang dapat membantu siswa untuk memperoleh keterampilan yang lebih baik (Salam et al., 2016). Untuk mengatasi masalah di atas, dilakukan rekayasa alat pemelajaran dengan judul penelitian "Pengembangan alat rotary table pada kompetensi cetak saring, program keahlian Desain dan Produksi Kriya Tekstil", dengan rumusan masalah 1) bagaimana bentuk pengembangan alat rotary table, 2) bagaimana cara menggunakannya dan 3) seberapa besar keefektifan penggunaan alat rotary table hasil pengembangan, dibandingkan dengan teknik cetak saring yang digunakan siswa selama ini.

Adapun tujuan penelitian untuk 1) menentukan bentuk pengembangan alat rotary table, 2) mengetahui cara menggunakan alat rotary table hasil pengembangan, dan 3) mengetahui perbandingan keefektifan penggunaan alat rotary table hasil pengembangan dengan teknik cetak saring yang digunakan selama ini. Pengembangan alat pembelajaran tersebut mengacu pada Permendiknas Nomor 40 tahun 2008 yang mengamanatkan tentang pemenuhan standar sarana dan prasarana pada pendidikan Sekolah Menengah Kejuruan (SMK) dalam standar minimal yang diharapkan dapat memberikan pelayanan maksimal terhadap peserta didik, sehingga tercipta sebuah proses pemelajaran yang efisien, efektif dan kompeten.

Borg \& Gall (1989) menyatakan sebuah penelitian pengembangan (research and development) merupakan sebuah metode yang digunakan untuk menvalidasi dan mengembangkan produk. Produk yang dimaksud pada penelitian ini adalah sebuah alat cetak yang digunakan dalam proses mencetak pada kompetensi sablon atau cetak saring. Sandhory (2006) menyatakan bahwa dalam ilmu grafika, mencetak dibagi menjadi empat bagian yaitu, cetak datar, cetak tinggi, cetak dalam dan cetak tembus. Salah satu contoh cetak tembus adalah cetak saring atau screen printing yang lebih dikenal dengan istilah cetak sablon. Cetak saring merupakan sebuah teknik pemberian motif atau gambar pada bidang gambar dengan proses penyaringan cat melalui alat saring yang disebut screen yang sebelumnya telah berisi motif sesuai dengan desain (Ruffels, 2002; Trantoul et al., 2011).

Memperoleh hasil cetak saring yang berkualitas dan sesuai dengan desain maka diperlukan ketelitian dan keterampilan serta alat bantu yang memadai, seperti meja cetak yang telah mengalami perkembangan bentuk yang kreatif dari pelaku sablon (Buivydiene dkk., 2019; Chang dkk., 2011; Pedersen \& Amirshahi, 2010; Porter Jr dkk., 2017). Alat Rotary Table merupakan meja putar yang 
berfungsi sebagai alas cetak yang dilengkapi dengan berbagai komponen sehingga memudahkan proses pencetakan baik ketepatan, kerapian ataupun kecepatan dengan hasil yang maksimal.

Menampilkan aneka alat rotary, dari yang sederhana, manual hingga masinal digital, namun selain bentuknya yang kurang efektif terutama untuk ruang sempit karena rata-rata dengan ukuran yang besar, juga harganya yang tidak berimbang dengan produk hasil pemelajaran (Di Flumeri dkk., 2019; Madhusudana dkk., 2016; Porter Jr dkk., 2017; Smith \& Bogatin, 2017). Penggunaan alat rotary table diharapkan meningkatkan keefektifan pemelajaran pada kompetensi cetak saring. Dalam hal ini dapat dilihat dari tingkat keberhasilan alat tersebut dalam memenuhi target pencetakan yang mampu melebihi kecepatan, ketepatan dan kerapian hasil cetak saring selama ini, yang ditandai dengan meningkatnya prestasi belajar siswa. Tercapainya tujuan pemelajaran secara maksimal yang kemudian disebut dengan pemelajaran efektif dipengaruhi oleh beberapa faktor antara lain, metode mengajar guru, intek atau kemampuan dasar dan keberagaman siswa serta dukungan sarana penunjang yang memadai.

(Lisniandila dkk., 2019) mengatakan bahwa peningkatan prestasi belajar siswa dipengaruhi oleh faktor yang sangat kompleks sehingga sulit dipisahkan antara satu dengan yang lainnya. Faktor-faktor tersebut dapat dikelompokkan menjadi dua yaitu, faktor intrinsik meliputi kemampuan pemahaman, pembentukan karakter hingga kesigapan dalam aspek psikomotorik peserta didik. Faktor lain adalah ekstrinsik terutama pada pemelajaran produktif kejuruan khususnya pada kompetensi membuat kriya tekstil dengan teknik cetak saring, adalah tersedianya berbagai media atau alat pemelajaran yang memadai. Pengembangan alat rotary table dimaksudkan sebagai alat pemelajaran di kelas khususnya, dan kepada masyarakat umum lainnya terutama dunia usaha dan dunia industri.

Hubungan antar variabel penelitian sebagai mana disebutkan di atas, dalam rangka peningkatan keefektifan produksi pada kompetensi cetak saring, dapat diuraikan sebagai berikut:

1. Hubungan antara Cetak Saring dengan Prestasi Belajar

Cetak saring atau screen printing merupakan salah satu kompetensi utama pada program keahlian DPK Tekstil. Walaupun perkembangan ilmu pengetahuan bidang grafis di era teknologi digital melaju dengan cepat, namun produk-produk cetak saring masih sangat diperlukan oleh masyarakat. Hal ini ditandai dengan tetap maraknya percetakan sablon yang berdampingan sejalan dengan alat teknologi digital printing, perusahaan cetak saring juga tetap ramai dengan order yang tidak mampu dikerjakan oleh digital printing.

Penggunaan teknik cetak saring sebagai media untuk ekspresi untuk memindahkan ide berupa hiasan pada $t$-shirt yang mampu bertahan, berjalan dan bahkan bersaing secara positif dengan teknik digital printing, menjadi salah satu faktor ekstrinsik siswa yang mampu memberikan motivasi belajar yang berdampak pada peningkatan prestasi belajar secara umum dan khususnya pada kompetensi cetak saring.

\section{Hubungan antara Alat Rotary Table dengan Prestasi Belajar}

Alat rotary table merupakan alat bantu utama yang digunakan dalam proses cetak saring. Penggunaan alat rotary table akan mempermudah, mempercepat dan menghasilkan produk cetak saring yang lebih sempurna dengan prinsip lebih efisien dan lebih efektif. Peningkatan prestasi belajar siswa pada kompetensi cetak saring ditentukan oleh beberapa aspek, salah satunya adalah proses percetakan, dimana kualitas hasil sangat ditentukan oleh teknik, 
pengalaman dan alat cetak yang digunakan. Alat rotary table merupakan alat cetak yang akan memberikan kemudahan dan kecepatan serta hasil yang lebih sempurna selama proses percetakan, sehingga terjadi peningkatan prestasi belajar bagi peserta didik.

3. Hubungan antara Cetak Saring, Alat Rotary Table, keefektifan pemelajaran terhadap prestasi belajar

Cetak saring merupakan sebuah kompetensi yang mengutamakan ketelitian, kecepatan, ketepatan dan kerapian hasil percetakan. Untuk meminimalisasi kesalahan siswa pada proses pencetakan, maka diperlukan alat bantu, berupa rotary table yang dapat berputar dan mampu mengontrol penempatan warna pada produk cetak saring dengan tingkat presisi yang maksimal.

Penggunaan hasil pengembangan alat rotary table akan memberikan dampak akselerasi pada proses percetakan, meminimalisasi tingkat kesalahan dengan kualitas cetakan yang maksimal sesuai dengan desain, sehingga terjadi keefektifan pemelajaran yang berdampak pada peningkatan prestasi/hasil belajar peserta didik.

Berdasarkan uraian di atas, maka dapat digambarkan kerangka berpikir seperti gambar 2.

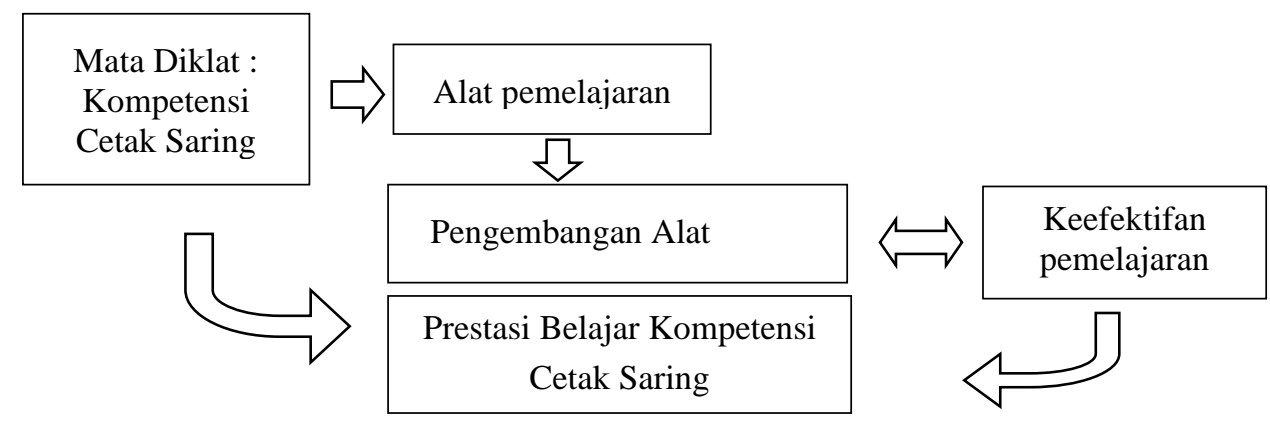

Gambar 2. Kerangka Berpikir Penelitian

Berdasarkan kajian teori pengembangan alat rotary table di atas maka hipotesis penelitian adalah alat rotary table hasil pengembangan memiliki tingkat keefektifan yang lebih tinggi jika dibandingkan dengan penggunaan alat cetak saring yang digunakan selama ini, yang berdampak pada meningkatkan prestasi belajar siswa pada kompetensi cetak saring.

\section{METODE PENELITIAN}

Penelitian ini menguunakan metode Research and Development $(R \& D)$. Menurut Creswell dan Creswell (2017), setidaknya ada 11 (sebelas) langkah yang dapat dilakukan guna memperoleh sebuah produk pengembangan. Adapun langkah dan kegiatan penelitian yang dilakukan adalah 1) Menemukan masalah, dimana siswa kesulitan melakukan percetakan terutama pada disain multi warna. 2) Mengumpulkan informasi. Peneliti mencari informasi tentang bentuk rotary table yang telah ada dengan segala kelebihan dan kekurangannya dari berbagai sumber. 3) Desain produk. Peneliti membuat rancangan alat rotary table dengan eksplorasi desain, menentukan desain terpilih dan membuat gambar kerja. 4) Validasi Desain, Peneliti berkonsultasi dengan ekspert judgement bidang praktisi, akademisi dan konstruksi, 5) Perbaikan desain, melakukan peninjauan dan revisi desain hingga benar-benar siap dilakukan produksi. 6) Pembuatan produk. Peneliti membuat 
prototype alat rotary table. 7) Uji Coba produk, Melakukan uji coba prototype dan mencatat kelebihan dan kekurangan untuk dilakukan revisi. 8) Revisi produk, melakukan revisi produk sesuai catatan dan rekomendasi selama uji coba produk. 9) Uji coba pemakaian. Uji coba tahap kedua untuk mencapai kesempurnaan alat rotary table. 10) Revisi produk, apabila masih terdapat kendala pada saat uji coba tahap kedua, maka diadakan revisi, namun jika dianggap sudah cukup maka dilakukan uji keefektifan (membandingkan dengan alat lama). 11) Pembuatan Produk Massal. Produk massal dilakukan setelah melalui uji keefektifan dan uji kelayakan alat.

Proses pengujian produk dilakukan melalui tiga tahap yaitu tahap pertama, dengan melakukan uji kelayakan alat dengan revisinya. Tahap kedua, merupakan uji penggunaan alat dan perbandingan keefektifan antara alat lama dengan alat hasil pengembangan. Tahap ketiga, merupakan tahapan revisi alat dan kesimpulan akhir.

Populasi dalam penelitian ini adalah siswa program studi Seni Rupa dan Kriya SMK Negeri 1 Sukasada, dengan sampel Kelas XI program keahlian Desain dan Produksi Kriya Tekstil tahun pelajaran 2018/2019 dengan jumlah siswa 15 (lima belas) orang.

Pengumpulan data menggunakan metode 1) Observasi, dengan menggunakan instrumen observasi terkait ergonomi selama proses uji coba produk. Pada kegiatan ini, peneliti mencatat segala gejala dan kendala yang dialami oleh responden, yang selanjutnya dicatat untuk mendapatkan tindak lanjut sebagai revisi produk. 2) Metode eksperimen, dilakukan untuk mendapatkan nilai produk yang dikerjakan oleh responden, dengan membandingkan hasil cetak antara penggunaan alat yang lama dengan alat rotary table hasil pengembangan, yang meliputi aspek kerapian, ketepatan dan kecepatan.

Skor tertinggi setiap aspek adalah 4 (empat) dan skor terendah adalah 1 (satu). Deskripsi setiap skor tersebut adalah 4 = Sangat (Rapi, Tepat, Cepat), 3 = Rapi, Tepat, Cepat, 2 = Cukup (Rapi, Tepat, Cepat), 1 = Kurang (Rapi, Tepat, Cepat). Khusus aspek kecepatan, karena aspek tersebut penilaiannya menggunakan waktu, sehingga hasil responden tersebut terlebih dahulu dikonversi menjadi angka yaitu 1 menit sampai 5 menit kualifikasi sangat baik dengan nilai 4 . Penggunaan waktu $>5$ menit sampai 10 menit kualifikasi baik dengan nilai 3. Penggunaan waktu $>10$ menit sampai 15 menit kualifikasi Cukup dengan nilai 2, dan Penggunaan waktu >15 menit kualifikasi Kurang dengan nilai 1.

Untuk mengetahui keefektifan dan efisiensi sebuah metode baru dengan metode lama maka, Sugiyono (2013) menyarankan perlu dilakukan uji signifikansi. Salah satu metode yang dapat dilakukan melalui eksperimen model before-after, yang dapat digambarkan seperti gambar 03 berikut.

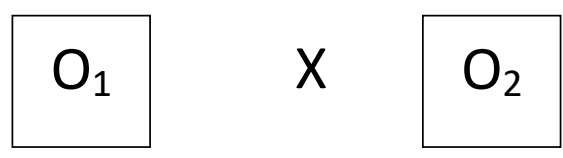

Gambar 3. Desain eksperimen (before-after)

Gambar 03 di atas menunjukkan bahwa eksperimen dilakukan dengan membandingkan hasil observasi $\mathrm{O}_{1}$ dan $\mathrm{O}_{2}$. $\mathrm{O}_{1}$ adalah nilai belajar yang diperoleh dari hasil alat yang lama, $\mathrm{O}_{2}$ adalah nilai yang diperoleh dari pembelajaran yang menggunakan alat rotary table yang baru. Keefektifan metode mengajar baru diukur dengan cara membandingkan antara nilai $\mathrm{O}_{2}$ dengan $\mathrm{O}_{1}$. Bila nilai $\mathrm{O}_{2}$ lebih besar daripada $\mathrm{O}_{1}$, maka metode mengajar tersebut efektif. 
Untuk menghitung perbandingan rata-rata keefektifan antara alat yang lama dengan alat yang baru dikembangkan, menurut Sugiyono (2013), ada 3 (tiga) langkah teknis yang harus dilakukan yaitu 1) menghitung rata-rata keefektifan metode lama dan baru, 2) menghitung persentase keefektifan kedua alat tersebut, 3) melakukan pembuktian signifikansi. Untuk memperoleh rata-rata nilai keefektifan, persentase keefektifan dan uji signifikansi tersebut, maka langkah yang dilakukan adalah sebagai berikut:

1. Menentukan rata-rata keefektifan penggunaan alat dengan cara pertama, menentukan skor kriterium (ideal) untuk alat yang dikembangkan dengan rumus: skor jawaban tertinggi x jumlah butir instrumen $\mathrm{x}$ jumlah responden, kedua, menentukan skor kriterium setiap butir instrumen dengan menggunakan rumus, skor tertinggi $x$ jumlah responden

2. Menentukan persentase keefektifan penggunaan alat dan instrumen dengan cara pertama, menentukan persentase penggunaan alat dengan menggunakan rumus: Jumlah nilai keseluruhan: skor kriterium, kedua, menentukan persentase nilai masing-masing instrumen dengan menggunakan rumus, Jumlah nilai masing-masing instrumen: skor kriterium instrumen.

3. Melakukan Pembuktian Signifikansi. Untuk membuktikan signifikansi perbedaan antara alat yang baru dan alat lama, maka perlu di uji statistik dengan $t$-test berkorelasi (related) dengan menggunakan program SPSS atau melakukan pengolahan data secara manual dengan menggunakan rumus:

$$
t=\frac{\bar{X}_{1}-\bar{X}_{2}}{\sqrt{\frac{s_{1}^{2}}{n_{1}}+\frac{s_{2}^{2}}{n_{2}}-2 r\left(\frac{s_{1}}{\sqrt{n_{1}}}\right)\left(\frac{s_{2}}{\sqrt{n_{2}}}\right)}}
$$

Dimana: X1

$$
\begin{array}{rll}
- & : & \text { Rata-rata sampel } 1 \text { (Alat lama), } \\
\mathrm{X}^{-} & : & \text {Rata-rata sampel } 2 \text { (Alat Baru) } \\
\mathrm{s} 1 & : & \text { Simpangan baku sampel 1 (Alat lama) } \\
\mathrm{s} 2 & : \text { Simpangan baku sampel } 2 \text { (Alat Baru) } \\
\mathrm{S}_{1}{ }^{2} & : \text { Varians sampel 1 (Alat lama) } \\
\mathrm{S}_{2}{ }^{2} & : \text { Varian sampel } 2 \text { (Alat Baru) } \\
\mathrm{r} & : \text { Korelasi antara data dua kelompok }
\end{array}
$$

Sebelum digunakan rumus tersebut, terlebih dahulu dicari korelasi nilai keefektifan alat yang baru dan lama, rata-rata, simpangan baku dan varians dari nilai total masing-masing alat. Dalam konteks rumus di atas, maka dalam penelitian ini ditetapkan hipotesis sebagai berikut.

Ho: Keefektifan alat hasil pengembangan lebih kecil atau sama dengan penggunaan alat yang lama $\left(\mu_{1} \leq \mu_{2}\right)$

Ha: Keefektifan alat hasil pengembangan lebih baik dari penggunaan alat yang lama $\left(\mu_{1}>\mu_{2}\right)$ 


\section{HASIL PENELITIAN DAN PEMBAHASAN}

Setelah melalui proses desain dan eksplorasi desain dengan segala revisinya maka diperoleh bentuk desain terpilih dari hasil pengembangan alat rotary table yang ideal maka diperoleh gambar perspektif dan proyeksi seperti pada gambar 4 dan 5 .

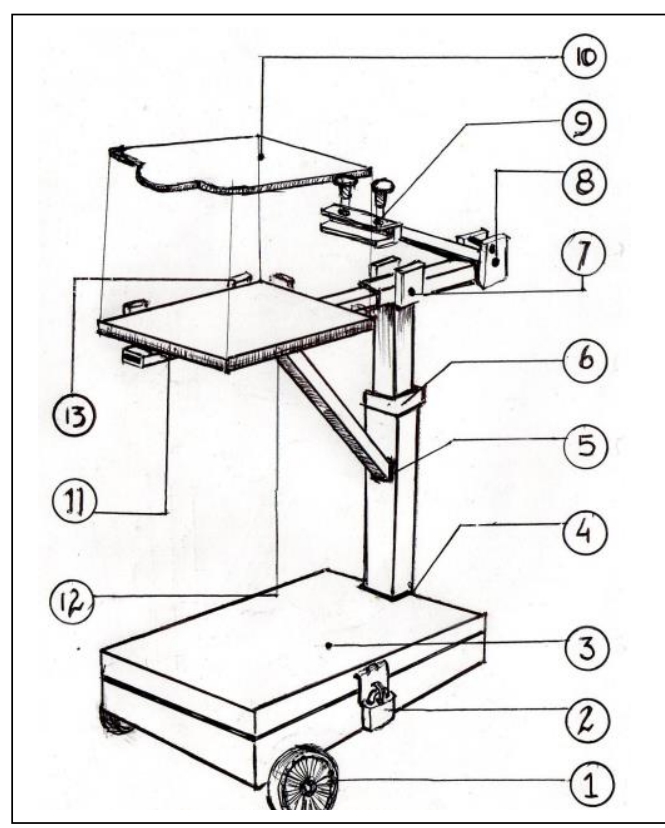

\section{Keterangan:}

1. Roda untuk memudahkan pemindahan alat

2. Gembok untuk pengaman

3. Kotak penyimpanan komponen (knock down)

4. Tempat pemasangan tiang bawah

5. Tempat Penyanggah bawah

6. Karet penghubung tiang atas dan bawah

7. pengunci gagang catok

8. Sumbu gerak naik dan turunnya gagang catok

9. Klem penjepit catok screen

10. Papan alas t-shirt

11. Papan alas cetak

12. Tempat penyanggah atas

13. Pengunci/ alat centering

Gambar 4. Gambar Perspektif

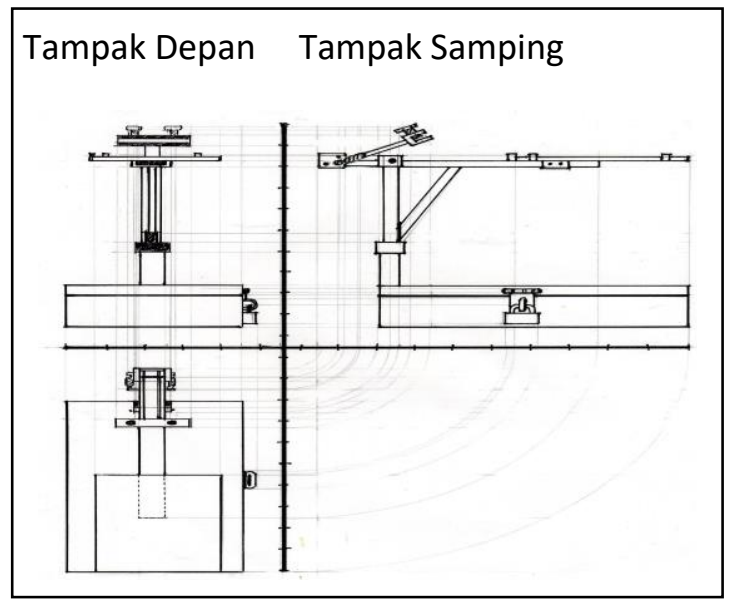

Gambar 5. Gambar Proyeksi Desain Terpilih

Tahapan pembuatan prototype alat rotary table, meliputi persiapan alat dan bahan berupa berbagai peralatan pertukangan kayu dan peralatan las listrik. Sedangkan bahan yang digunakan terdiri dari pipa besi berbagai ukuran, engsel, baut, besi plat, papan multipleks, tripleks dan cat untuk finishing, dengan langkah pembuatan sebagai berikut: 1) Siapkan bahan yang diperlukan, 2) Pembuatan kotak komponen yang sekaligus sebagai alas rotary table, 3) Pemasangan engsel untuk menyatukan antara 
kotak dan tutupnya, 4) Pembuatan tiang bawah, tiang atas, tempat stick dan komponen lainnya serta stick dan gagang catok, 5) Finishing rangka kotak alas dan rangka besi lainnya, dengan cat dasar warna hitam lapis bintik silver, dan terakhir cat clear, 6) Pembuatan dan pemasangan dinding kotak, dengan menggunakan paku piser dari luar, 7) Membuat papan alas cetak, yang dilengkapi dua buah klem (pipa bentuk $U$ ) dari sisi bawah dan pemasangan alat centering pada sisi kiri dan sisi depan serta sisi kanan, 8) Membuat papan pelapis berupa tripleks $1 \mathrm{~cm}$ ukuran $40 \mathrm{~cm}$ X $36 \mathrm{~cm}$ berbentuk leher pada salah satu sisi panjang papan pelapis dengan menggunakan mesin scrool. Haluskan dengan menggunakan ampelas. Lapisi salah satu permukaan dengan lem kain (hidronol), 9) Pemasangan komponen alat rotary table, sehingga membentuk satu kesatuan alat rotary table yang utuh, lakukan finising cat dengan menggunakan cat semprot pylox pada seluruh bagian alat kecuali pada komponen papan pelapis $t$-shirt.

Tahap uji keefektifan, revisi dan validasi produk dilakukan sebanyak dua kali dengan hasil akhir perbandingan antara alat lama dengan penggunaan alat rotary table sebagaimana ditunjuk tabel 2 .

Tabel 2. Hasil Uji Keefektifan Alat Lama dan Rotary Table

\begin{tabular}{|c|c|c|c|c|c|c|c|c|c|c|}
\hline \multirow{3}{*}{ No } & \multirow{3}{*}{$\begin{array}{l}\text { Kode } \\
\text { Respon } \\
\text { den }\end{array}$} & \multicolumn{8}{|c|}{ Skor Aktivitas } & \multirow[t]{3}{*}{ Keterangan } \\
\hline & & \multicolumn{4}{|c|}{ Alat Lama } & \multicolumn{4}{|c|}{ Alat Rotary Table } & \\
\hline & & $\mathrm{A}$ & B & $\mathrm{C}$ & Jumlah & A & B & $\mathrm{C}$ & Jumlah & \\
\hline 1 & 01 & 75 & 75 & 75 & 225 & 89 & 93 & 87 & 269 & \multirow{5}{*}{$\begin{aligned} A= & \text { Kecepatan dengan } \\
& \text { konversi nilai: } \\
& \geq 1,6 \text { menit, Nilai } \leq 70 .\end{aligned}$} \\
\hline 2 & 02 & 76 & 75 & 75 & 226 & 87 & 88 & 86 & 261 & \\
\hline 3 & 03 & 74 & 76 & 76 & 226 & 90 & 90 & 87 & 267 & \\
\hline 4 & 04 & 65 & 85 & 76 & 226 & 89 & 85 & 85 & 259 & \\
\hline 5 & 05 & 75 & 75 & 75 & 225 & 96 & 95 & 85 & 276 & \\
\hline 6 & 06 & 77 & 80 & 76 & 233 & 86 & 87 & 83 & 256 & \multirow{2}{*}{$\begin{array}{l}1,1 \text { menit sd. } 1,5 \text {, menit, } \\
\text { Nilai } 70 \text { - } 79\end{array}$} \\
\hline 7 & 07 & 79 & 89 & 75 & 243 & 86 & 93 & 87 & 266 & \\
\hline 8 & 08 & 77 & 75 & 75 & 227 & 78 & 88 & 89 & 255 & \multirow{3}{*}{$\begin{array}{l}16 \text { detik sd } 1 \text { menit } \\
\text { Nilai } 80-89\end{array}$} \\
\hline 9 & 09 & 74 & 80 & 77 & 231 & 90 & 92 & 90 & 272 & \\
\hline 10 & 010 & 77 & 78 & 76 & 231 & 87 & 89 & 88 & 264 & \\
\hline 11 & 011 & 77 & 79 & 77 & 233 & 79 & 95 & 85 & 259 & \multirow{2}{*}{$\begin{array}{l}\leq 15 \text { detik, Nilai } 90- \\
100\end{array}$} \\
\hline 12 & 012 & 78 & 87 & 77 & 242 & 95 & 88 & 89 & 272 & \\
\hline 13 & 013 & 79 & 89 & 77 & 245 & 78 & 96 & 83 & 257 & \multirow{4}{*}{$\begin{array}{l}\mathrm{B}=\text { Ketepatan } \\
\mathrm{C}=\text { Kerapian }\end{array}$} \\
\hline 14 & 014 & 77 & 79 & 76 & 232 & 80 & 89 & 88 & 257 & \\
\hline 15 & 015 & 74 & 86 & 76 & 236 & 90 & 92 & 89 & 271 & \\
\hline \multicolumn{2}{|c|}{ Jumlah } & 1134 & 1208 & 1139 & 3481 & 1300 & 1359 & 1301 & 3961 & \\
\hline
\end{tabular}

Berdasarkan hasil analisis data dalam pengujian keefektifan maka perbandingan antara kedua alat tersebut sebagaimana ditunjukkan pada tabel 3 dibawah ini: 
Tabel 3. Perbandingan Keefektifan Alat Lama dan Alat Rotary Table

\begin{tabular}{ccc}
\hline Alat Lama $(\%)$ & Aktivitas & Alat Rotary Table $(\%)$ \\
\hline 79 & Kecepatan & 90 \\
\hline 84 & Ketepatan & 94 \\
\hline 83 & Kerapian & 90 \\
\hline 82,0 & Rata-Rata & 91,3 \\
\hline
\end{tabular}

Berdasarkan tabel 3 di atas terlihat bahwa keefektifan penggunaan alat rotary table lebih tinggi dari pada keefektifan penggunaan alat yang lama dengan perbandingan 91,3\%:82,0\%, jika ditampilkan dalam bentuk grafik, maka akan terlihat seperti gambar 06 sebagai berikut:

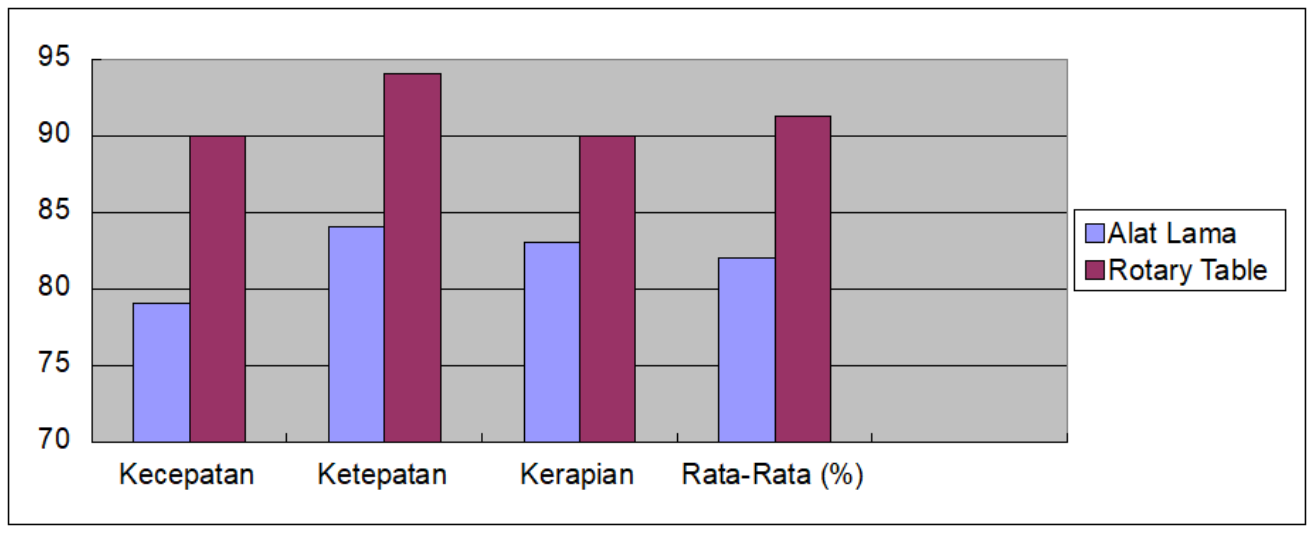

Gambar 6. Grafik Perbandingan Keefektifan Antara Alat Lama dengan Alat Rotary Table Tingkat signifikansi perbedaan kedua alat diuji dengan statistik komparasi Paired sampel t-test dengan hasil pengolahan data sebagaimana tertera pada tabel 4 .

Tabel 4. Korelasi Nilai Keefektifan Kedua Alat Tahap Kedua

\begin{tabular}{ccc}
\hline \multirow{2}{*}{$\begin{array}{c}\text { Kode } \\
\text { responden }\end{array}$} & \multicolumn{2}{c}{ Jumlah Nilai Keefektifan } \\
\cline { 2 - 3 } & $(\mathrm{X} 1)$ & Alat Rotary Table $(\mathrm{X} 2)$ \\
\hline 01 & 225 & 269 \\
\hline 02 & 226 & 261 \\
\hline 03 & 226 & 267 \\
\hline 04 & 226 & 259 \\
\hline 05 & 225 & 276 \\
\hline 06 & 233 & 256 \\
\hline 07 & 243 & 266 \\
\hline 08 & 227 & 255 \\
\hline 09 & 231 & 272 \\
\hline 010 & 231 & 264 \\
\hline 011 & 233 & 259 \\
\hline
\end{tabular}




\begin{tabular}{ccc}
\hline \multirow{2}{*}{$\begin{array}{c}\text { Kode } \\
\text { responden }\end{array}$} & \multicolumn{2}{c}{ Jumlah Nilai Keefektifan } \\
\cline { 2 - 3 } & $(\mathrm{X} 1)$ & Alat Rotary Table $(\mathrm{X} 2)$ \\
\hline 012 & 242 & 272 \\
\hline 013 & 245 & 257 \\
\hline 014 & 232 & 257 \\
\hline 015 & 236 & 271 \\
\hline$\sum \mathrm{X}$ & 3481 & 3961 \\
\hline $\bar{X}$ & $\mathbf{2 3 2 , 1}$ & $\mathbf{2 6 4 , 1}$ \\
\hline $\mathrm{S}$ & 6,8 & 6.9 \\
\hline $\mathrm{S} 2$ & 46,2 & -040 \\
\hline $\mathrm{r}$ & -040 & \\
\hline $\mathrm{t}$ & & $\mathbf{- 1 2 , 6}$ \\
\hline
\end{tabular}

Untuk membuat keputusan, apakah perbedaan ini signifikan atau tidak, maka harga t-hitung di atas perlu dibandingkan dengan harga t-tabel dengan $\mathrm{dk} n$ (jumlah responden 15) $-2=13$. Berdasarkan tabel nilai-nilai dalam distribusi t (Sugiono, 2013:372), bila dk 13, untuk uji satu pihak dengan taraf kesalahan 5\% maka harga $t$ tabel = 1,77 Bila harga t- hitung jatuh pada daerah penerimaan Ha, maka Ha yang menyatakan bahwa penggunaan alat Rotary table hasil pengembangan, lebih efektif dari penggunaan alat yang lama.

Hasil perhitungan, t-hitung -12,6 jatuh pada penerimaan $\mathrm{Ha}$ atau penolakan Ho, sebagaimana ditunjukkan pada gambar 7 di bawah ini.

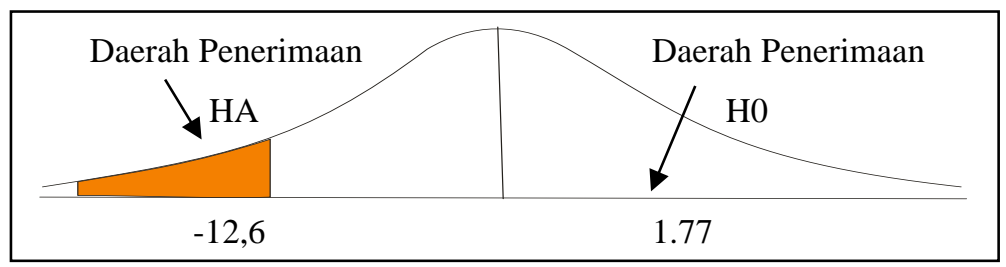

Gambar 7. Uji Hipotesis Pihak Kanan. t hitung -12,6

Dengan demikian disimpulkan bahwa terdapat perbedaan yang signifikan (dapat digeneralisasikan) keefektifan antara kedua alat, dimana penggunaan alat rotary table hasil pengembangan lebih efektif dari pada penggunaan alat cetak saring yang digunakan selama ini.

\section{SIMPULAN DAN SARAN}

Bentuk alat rotary table hasil pengembangan, secara umum memiliki ketinggian yang dapat diatur sehingga memberikan kenyamanan kepada penggunanya. Kedua, pada bagian alas cetak dilengkapi beberapa bagian alat pengunci yang memudahkan penggunanya untuk melakukan centring yang menjamin ketepatan dan kecepatan pada proses pencetakan.

Langkah penggunaan alat rotary table hasil pengembangan. Pertama, memasang rangkaian alat rotary table dengan tahapan, 1) buka penutup kotak tempat penyimpanan komponen alat, 2) putar tiang 
penyanggah ke atas hingga berdiri tegak lurus lalu dikunci agar tidak bergerak. Tarik ke atas kedua roda hingga tidak menyentuh lantai kemudian dikunci pada posisi yang sudah tersedia, 3) tarik tiang penyanggah bagian atas sesuai dengan ketinggian yang diinginkan dengan mempertimbangkan kenyamanan penggunanya. Kunci agar tetap pada posisinya (tidak bergerak), 4) pasang stick pada tempatnya lalu dikencangkan baut pengikatnya agar tidak bergerak. Pasang komponen catok dan papan alas masing-masing pada tempatnya, lalu dikencangkan baut pengunci.

Langkah kedua, Proses Pencetakan dengan tahapan 1) pasang $t$-shirt pada papan pelapis yang telah berisi lem $t$-shirt, ratakan hingga gelembung kain hilang, 2) pasang papan pelapis yang telah berisi $t$ shirt, pada papan alas dengan sisi-sisi tepat pada alat centering, pertahankan posisi ini dan pastikan tidak bergeser selama proses pencetakan, 3) pasang screen (film negatif) untuk warna pertama pada catok dengan kondisi setengah kunci, turunkan hingga menyentuh $t$-shirt, atur posisi gambar sesuai dengan desain. Kencangkan kunci catok hingga tidak dapat bergeser, 4) lakukan proses pecetakan sebagaimana langkah mencetak sablon seperti biasanya, 5) angkat hasil cetakan, lakukan pengeringan dengan mengangin-anginkan, 6) ulangi langkah 2 sampai 5, untuk proses pencetakan berikutnya sesuai dengan jumlah eksemplar dan jumlah warna yang akan dicetak. Tahap ketiga merupakan proses finishing yaitu mengeluarkan $t$-shirt dari papan alas cetak kemudian melakukan proses fiksasi dengan cara pemanasan/strika yang menggunakan strika panas sesuai dengan kekuatan kain.

Perbandingan keefektifan penggunaan alat rotary table hasil pengembangan dengan alat yang digunakan selama ini tercatat aspek kecepatan 90\%: 79\%, aspek ketepatan 94\%: $84 \%$ dan aspek kerapian sebesar 90\%: $83 \%$, dengan rata-rata $91,3 \%: 82,0 \%$.

Berdasarkan simpulan di atas, maka disarankan agar ada upaya sekolah memberikan apresiasi kepada siswa, pegawai dan guru yang mampu memperlihatkan kreativitasnya sehingga prestasi akan menjadi budaya bagi warga sekolah. Guru yang mengajar kompetensi cetak saring agar memanfaatkan alat rotary table hasil pengembangan sebagai salah satu alat cetak yang dapat membantu proses pencetakan yang akan berdampak pada prestasi belajar siswa. Dunia Usaha dan Dunia Industri (DU/DI) sebaiknya senantiasa memberikan masukan atas segala kelemahan pemelajaran dari aspek dunia usaha yang dilakukan oleh sekolah sekaligus berbagi ilmu untuk kepentingan siswa dan kemajuan pendidikan Indonesia secara umum.

\section{DAFTAR RUJUKAN}

Borg, W., \& Gall, M. (1989). The methods \& tools of observational research. Educational Research: An Introduction, 473-530.

Buivydiene, D., Krugly, E., Ciuzas, D., Tichonovas, M., Kliucininkas, L., \& Martuzevicius, D. (2019). Formation \& characterisation of air filter material printed by melt electrospinning. Journal of Aerosol Science, 131, 48-63.

Chang, C., Chiu, C., \& Lee, Y. (2011). P-117: Direct Printed Plastic Color Filter for Color Electrophoretic Displays. Sid Symposium Digest of Technical Papers, 42(1), 1545-1547.

Creswell, J. W., \& Creswell, J. D. (2017). Research design: Qualitative, quantitative, \& mixed methods approaches. Sage publications. 
Di Flumeri, G., Aricò, P., Borghini, G., Sciaraffa, N., Di Florio, A., \& Babiloni, F. (2019). The dry revolution: evaluation of three different EEG dry electrode types in terms of signal spectral features, mental states classification \& usability. Sensors, 19(6), 1365.

Lisniandila, N. P. A., Santyasa, I. W., \& Suswandi, I. (2019). The Effect of Problem Based Learning Teaching Method on Students' Critical Thinking Skills in Physics Lesson at SMA Negeri 4 Singaraja. JPP (Jurnal Pendidikan dan Pembelajaran), 25(1), 16-24.

Madhusudana, C. K., Kumar, H., \& Narendranath, S. (2016). Condition monitoring of face milling tool using K-star algorithm \& histogram features of vibration signal. Engineering Science and Technology, an International Journal, 19(3), 1543-1551.

Pedersen, M., \& Amirshahi, S. A. (2010). Framework for the evaluation of color prints using image quality metrics. Conference on Colour in Graphics, Imaging, \& Vision, 2010(1), 75-82.

Porter Jr, L. A., Chapman, C. A., \& Alaniz, J. A. (2017). Simple \& inexpensive 3D printed filter fluorometer designs: User-friendly instrument models for laboratory learning \& outreach activities. ACS Publications.

Ruffels, T. D. (2002). Subjective response to Place through convergent strategies in Digital Imaging \& Print processes. University of Tasmania.

Salam, R., Zunaira, Z., \& Niswaty, R. (2016). Meningkatkan Hasil Belajar Membuat Dokumen melalui Penggunaan Model Pembelajaran Kooperatif Tipe Make a Match (Mencari Pasangan). Jurnal Office, 2(2), 173-180.

Sandhory, N. (2006). Pengetahuan \& Keterampilan Sablon (Screen Printing). Angkasa.

Smith, L. D., \& Bogatin, E. (2017). Principles of Power Integrity for PDN Design--Simplified: Robust \& Cost Effective Design for High Speed Digital Products. Prentice Hall.

Sugiyono. (2013). Statistika untuk Penelitian. Alfabeta.

Trantoul, F., Philippe, E., \& Bes, L. (2011). Method of producing a transparent polychromatic printed iridescent image. Google Patents. 